\title{
MA Defence: "Shopping for Change: An Ideological Retelling/Retailing of Charitable Aid in World Vision Canada's Charity Gift Catalogue" by Vincci Li
}

\section{Sibo Chen}

School of Communication

Simon Fraser University

Our dear colleague, Vincci Li, will defend her MA Thesis on Friday, September 25th, 2015 at Harbour Centre, Room 1700 (10 am -12 noon). Here is the abstract of her thesis "Shopping for Change":

\begin{abstract}
Since the early 2000s, a growing number of charitable organizations has introduced gift catalogues from which donors "shop" through tangible goods (e.g. livestock, mosquito nets) for recipients in need. Building upon the work of Susan Willis, I approach the charity gift catalogue as a form of ideological packaging. This thesis critically analyzes World Vision Canada's gift catalogues to explore how the consumption-oriented language and format of the catalogue commodify charitable aid and its recipients. Specifically, I examine how the catalogue transforms charitable aid into "products" by a) standardizing quantities b) creating an appearance of use value and c) aestheticizing charitable aid as a "shopping" experience. This project aims to establish an understanding of "shopping" from a charity catalogue as more than a playful metaphor; rather, it is an ideological representation that may negatively shape the way in which donors conceptualize and participate in charitable aid in the long term.
\end{abstract}

Keywords: charity; World Vision; gift catalogue; commodification; ideology 